\title{
The failure of prolactin to enhance the inhibitory effect of oestradiol-17ß on LH synthesis and release in ewes
}

\author{
P. J. Wright, J. K. Findlay* and G. A. Anderson
}

Department of Veterinary Clinical Sciences, University of Melbourne, Werribee, 3030, and *Medical Research Centre, Prince Henry's Hospital, St. Kilda Road, Melbourne, 3004, Australia

\begin{abstract}
Summary. Groups of 5-6 ovariectomized ewes were treated with oestradiol-17 $\beta$ (100 mg implant) and/or bromocriptine $(1 \mathrm{mg} ; 2 \times$ daily) or with vehicle for 30 days during the anoestrous season. Oestradiol increased $(P<0.05)$ the priming effect of $2 \times 1 \mu \mathrm{g} \mathrm{LH}-\mathrm{RH}$ on $\mathrm{LH}$ release and decreased $(P<0.001)$ pituitary LH content, plasma LH levels, the frequency and amplitude of pulsatile $\mathrm{LH}$ release and the $\mathrm{LH}$ response to LH-RH. Bromocriptine decreased prolactin levels to $<2.5 \mathrm{ng} / \mathrm{ml}(P<$ $0.001)$ and increased the LH response to LH-RH $(P<0.05)$. There were no significant treatment interactions. It is concluded that prolactin does not enhance the inhibitory effect of oestradiol on LH synthesis and release in the ewe.
\end{abstract}

\section{Introduction}

Ovarian acyclicity in ewes is associated with elevated plasma prolactin levels and an increase in the inhibitory effect of oestradiol-17 $\beta$ on $\mathrm{LH}$ release. During both seasonal and post-partum anoestrus, when prolactin levels are raised (Walton, McNeilly, McNeilly \& Cunningham, 1977; Thimonier, Ravault \& Ortavant, 1978; Kann \& Martinet, 1975; Kann, Habert, Meusnier \& Ryniewicz, 1977), there is evidence of an enhanced inhibitory effect of oestradiol-17 $\beta$ on $\mathbf{L H}$ release (Legan, Karsch \& Foster, 1977; Wright, Geytenbeek, Clarke \& Findlay, 1981). Treatments that reduce plasma prolactin levels post partum, such as udder denervation (Kann \& Martinet, 1975), administration of bromocriptine (Kann, Martinet \& Schirar, 1978), or early lamb removal (Mauleon \& Dauzier, 1965; Shevah, Black, Carr \& Land, 1974), can hasten the onset of ovarian cyclicity post partum. This suggests that high prolactin levels may be causally related to ovarian acyclicity by increasing the inhibitory effect of oestradiol on $\mathrm{LH}$ release. We have investigated the relationship between prolactin levels and the inhibition of LH release by oestradiol in ovariectomized ewes during the anoestrous season.

\section{Materials and Methods}

Animals and experimental design

The experiment was conducted at the Animal Research Institute, Werribee, Victoria, Australia, during the anoestrous season (November, 1977).

Twenty-three mature Corriedale ewes were ovariectomized; treatment commenced immediately (Day 1) and continued until autopsy (Day 30). Five ewes received s.c. Silastic (Dow Corning, U.S.A.) implants containing oestradiol-17 $\beta$ (Ikapharm, Israel, 95-105 mg) (Karsch et 
al., 1973). Six ewes received bromocriptine (Sandoz, Switzeriand; $1 \mathrm{mg}$ in $2 \mathrm{ml} 60 \%$ ethanol-- $0.154 \mathrm{M}-\mathrm{NaCl}$ i.m.) twice daily to reduce plasma prolactin levels (Niswender, 1974). Six ewes received both oestradiol and bromocriptine treatments and 6 control ewes received $2 \mathrm{ml}$ vehicle (60\% ethanol in $0.154 \mathrm{M}-\mathrm{NaCl}$ i.m.) twice daily. Blood samples were taken every $20 \mathrm{~min}$ via jugular vein cannulae on the day before ovariectomy (Day -1 ) for $6 \mathrm{~h}$ and on Day 21 for 12 h. On Day 23, pituitary responsiveness to LH-RH was assessed; the ewes received two i.v.

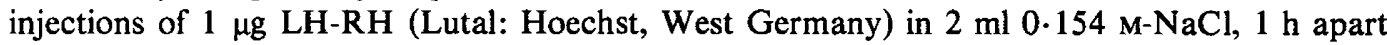
(Stelmasiak \& Galloway, 1977). Blood samples $(8 \mathrm{ml})$ were taken via jugular vein cannulae into heparinized syringes at 10-min intervals from 20 min before to $1 \mathrm{~h}$ after the second LH-RH injection. All blood samples were centrifuged promptly and the plasma stored at $-20^{\circ} \mathrm{C}$ until assayed for $\mathrm{LH}$ and prolactin.

Seven days after assessment of LH-RH responsiveness the ewes were autopsied (Day 30), the pituitaries removed and stored at $-20^{\circ} \mathrm{C}$. The procedure for extraction of $\mathrm{LH}$ from the pituitary glands was similar to that described by Foster et al. (1972). Each pituitary was thawed, diced and homogenized in $10 \mathrm{ml} 0.1 \mathrm{M}-\left(\mathrm{NH}_{4}\right)_{2} \mathrm{SO}_{4}\left(\mathrm{pH} \mathrm{5.5)}\right.$ at $4^{\circ} \mathrm{C}$. The homogenate was then centrifuged at $17000 \mathrm{~g}$ at $4^{\circ} \mathrm{C}$ for $30 \mathrm{~min}$. The supernatant was decanted and stored at $-20^{\circ} \mathrm{C}$ until assay. LH determinations on pituitary extracts were made in quadruplicate at dilutions of $1: 20000$ and $1: 40000$ in assay buffer $(0.05 \mathrm{M}$-phosphate buffer, $\mathrm{pH} 7 \cdot 0$, containing $\mathrm{NaCl}$ $(0.15 \mathrm{M})$, human albumin $(0.1 \% \mathrm{w} / \mathrm{v})$, iodoacetamide $(0.05 \% \mathrm{w} / \mathrm{v})$ and merthiolate $(0.01 \%$ $\mathrm{w} / \mathrm{v}))$.

\section{Hormone assays}

LH. Plasma and pituitary LH concentrations were measured by a double-antibody radioimmunoassay (Stelmasiak \& Galloway, 1977), using horse anti-bovine LH serum (Snook, 1968), goat anti-horse gamma globulin, NIH-LH-S18 (biopotency $1.02 \times$ NIH-LH-S1) as standard and Papkoff LH (G3222B; biopotency $2.69 \times$ NIH-LH-S1) for iodination by the chloramine T method (Greenwood, Hunter \& Glover, 1963). LH concentrations and assay quality control data were calculated using the methods and computer programme of Burger, Lee $\&$ Rennie (1972). The study included 3 assays. The mean ( \pm s.e.m.) sensitivity was $0.15 \pm 0.02$ $\mathrm{ng} / \mathrm{ml}$. The within-assay coefficient of variation was $<20 \%$ over the range $0.53 \pm 0.09$ to $26.3 \pm$ $2.2 \mathrm{ng} / \mathrm{ml}$. The interassay coefficients of variation were $13 \%(0.8 \pm 0.06 \mathrm{ng} / \mathrm{ml}), 20 \%(12.7 \pm$ $1.4 \mathrm{ng} / \mathrm{ml})$ and $16 \%(22.0 \pm 2.1 \mathrm{ng} / \mathrm{ml})$.

Prolactin. Plasma prolactin levels were measured by a double-antibody assay developed in this laboratory. Rabbit anti-ovine prolactin (NIH-P-S8) serum was used at a final dilution of 1:16 000. Iodination of prolactin (LER-860-2; biopotency 30 i.u. $/ \mathrm{mg}$ ) was performed using a lactoperoxidase method similar to that of Rogol \& Rosen (1974). The assay standard was NIH-P-S8 (biopotency 28 i.u./mg). Horse anti-rabbit serum was used as second antibody at a final dilution of $1: 75$. Cross reactivities with other ovine protein hormones were $<1 \%$ for $\mathrm{LH}$ (NIH-LH-S18), FSH (NIH-FSH-S6) and TSH (NIH-TSH-S5) and 5\% for GH (NIH-GH-S11). Serial dilutions of a pool of ovine plasma gave values (mean \pm s.e.m., $n=10$ ) of $1.4 \pm 0 \cdot 10$, $0.68 \pm 0.02,0.32 \pm 0.06$ and $0.16 \pm 0.03 \mathrm{ng}$ prolactin/tube $(r>0.99 ; P<0.001)$. Serial dilutions of ewe plasma and of the prolactin standards in assay buffer gave parallel inhibition curves $\left(y=41.7-25 \cdot 7 x, y=43.7-24 \cdot 7 x\right.$, where $y=\mathrm{B} / \mathrm{B}_{0} \%, x=\log _{\mathrm{e}} \mathrm{ng}$ prolactin/tube).

Prolactin levels were determined in the plasma samples taken on Day 21 over the second 6-h period. Samples were diluted $1: 10$ in assay buffer $(0.04 \mathrm{M}$-phosphate buffer, $\mathrm{pH} 7.4$, containing $0.15 \mathrm{M}-\mathrm{NaCl}, 0.01 \mathrm{M}$-EDTA, $0.5 \%(\mathrm{w} / \mathrm{v})$ BSA and $0.1 \%(\mathrm{w} / \mathrm{v})$ sodium azide) and assayed in duplicate using $100 \mu \mathrm{l}$ diluted plasma. All values were determined in the one assay. Prolactin concentrations and assay quality control data were calculated using the methods and computer programme of Burger et al. (1972). The assay sensitivity was $2.5 \mathrm{ng} / \mathrm{ml}$ and the intra-assay coefficient of variation was $<20 \%$ over the range $5 \cdot 3-161 \mathrm{ng} / \mathrm{ml}$ and was $8 \%$ at $35 \mathrm{ng} / \mathrm{ml}$. 
Analysis of results

Treatment effects were assessed by comparison of hormone levels on a within-assay basis only. For each ewe the plasma LH levels for the series of blood samples taken to determine $\mathrm{LH}$ release patterns were analysed in terms of mean $\mathrm{LH}$ levels, and of the frequency and amplitude of short-term elevations of plasma $\mathrm{LH}$ concentrations that reflected pulsatile discharges (pulses) of the hormone from the pituitary gland. An LH pulse was identified when the plasma concentrations in one or a series of samples was at least $1 \mathrm{ng} / \mathrm{ml}$ and greater than the level in preceding and/or following samples by a factor of at least 4 times the coefficient of variation of the assay. Pulse amplitude was the maximum plasma LH concentration associated with the pulse minus the concentration preceding the pulse. These definitions are the same as those used by Wright et al. (1981) and similar to those of Baird (1978) and Lincoln (1978). The response to the first injection of LH-RH ( $1 \mu \mathrm{g}$ i.v.) was determined as the integrated area under the plasma LH concentration against time curve (ng. $\mathrm{ml}^{-1} . \mathrm{h}$ ) derived from blood samples taken each $10 \mathrm{~min}$ for $1 \mathrm{~h}$ from injection. The response to the second injection of LH-RH was similarly calculated and corrected for the estimated residual response to the first injection. This was done by assuming a half-life of $24 \mathrm{~min}$ for the plasma $\mathrm{LH}$ present at the time of the second injection (Geschwind \& Dewey, 1968; Kaltenbach, Schroff, Klindt \& Dunn, 1972) and subtracting its contribution to the concentration-time curve following the second injection. Peak values were noted 10 or 20 min after each injection in all groups. The LH-RH priming effect ratio, a measure of increasing pituitary responsiveness to successive small doses of $\mathrm{LH}-\mathrm{RH}$, was the response to the second injection expressed as a ratio of the response to the first injection. Total LH-RH responsiveness was the integrated area under the plasma $\mathrm{LH}$ concentration-time curve from the first injection to $1 \mathrm{~h}$ after the second. These methods are similar to those of Stelmasiak \& Galloway (1977).

The effects of bromocriptine and of oestradiol on pituitary LH content, plasma LH levels, the frequency and amplitude of $\mathrm{LH}$ pulse, LH-RH responsiveness and LH-RH priming effect, and plasma prolactin levels were analysed using $2 \times 2$ analyses of variance. An alteration (increase or decrease) in the inhibitory effects of oestradiol on characters reflecting $\mathrm{LH}$ synthesis and release associated with bromocriptine-induced reduction in plasma prolactin levels would manifest itself as a significant interaction effect. When necessary log transformations were performed to render variances compatible.

\section{Results}

Before ovariectomy, the overall mean ( \pm s.e.m.) plasma LH level, pulse frequency and amplitude were $2 \cdot 13 \pm 0.23 \mathrm{ng} / \mathrm{ml}, 1.46 \pm 0.23 \mathrm{pulses} / 6 \mathrm{~h}$ and $1.8 \pm 0.14 \mathrm{ng} / \mathrm{ml}$. Oestradiol treatment of ovariectomized ewes increased $(P<0.05)$ the LH-RH priming effect ratio and decreased $(P<$ 0.001 ) the pituitary LH content, plasma LH levels, LH-RH responsiveness, $\mathrm{LH}$ pulse frequency and amplitude (Tables 1 and 2).

Bromocriptine treatment reduced plasma prolactin levels $(P<0.001)$, and increased LH-RH responsiveness $(P<0.05)$ but had no significant effects $(P>0.05)$ on plasma LH levels, LH pulse frequency or amplitude or on pituitary LH content $(0.05<P<0.1)$. There were no significant interactions (Table 2).

\section{Discussion}

Chronic treatment of ovariectomized ewes with oestradiol during the anoestrous season had a pronounced inhibitory effect on plasma LH levels, a finding similar to that described by Legan et 
Table 1. The effect of oestradiol-17 $\beta$ and bromocriptine on pituitary LH and on plasma LH and prolactin in ovariectomized Corriedale ewes during the anoestrous season

\begin{tabular}{lcccc}
\hline & \multicolumn{4}{c}{ Treatment } \\
\cline { 2 - 5 } & Control & Oestradiol & Bromocriptine & $\begin{array}{c}\text { Oestradiol }+ \\
\text { bromocriptine }\end{array}$ \\
\hline No. of ewes & 6 & 5 & 6 & 6 \\
Plasma LH (ng/ml) & $5.03 \pm 0.68$ & $0.58 \pm 0.07$ & $6.08 \pm 1.16$ & $0.76 \pm 0.04$ \\
No. ewes with LH pulses & 6 & 2 & 6 & 3 \\
LH pulse frequency (pulses/12 h) & $11.9 \pm 0.7$ & $0.3 \pm 0.2$ & $12.2 \pm 0.9$ & $0.6 \pm 0.3$ \\
LH pulse amplitude (ng/ml) & $6.2 \pm 0.9$ & $2.8 \pm 0.3$ & $8.7 \pm 2.3$ & $2.7 \pm 0.3$ \\
LH-RH responsiveness (ng/ml . h) & $34 \pm 5.4$ & $4 \cdot 7 \pm 0.6$ & $47 \pm 9.2$ & $9.2 \pm 1.9$ \\
LH-RH priming effect ratio & $1.3 \pm 0.2$ & $1.6 \pm 0.3$ & $1.4 \pm 0.08$ & $1.9 \pm 0.18$ \\
Pituitary LH content (mg/gland) & $1.51 \pm 0.17$ & $0.26 \pm 0.02$ & $1.71 \pm 0.3$ & $0.39 \pm 0.04$ \\
Plasma prolactin (ng/ml) & $71 \pm 11$ & $89 \pm 19$ & $<2.5$ & $<2.5$ \\
\hline
\end{tabular}

Values are mean \pm s.e.m.

Table 2. The significance of main effects (oestrogen, bromocriptine) and of the interaction effect derived from $2 \times 2$ analyses of variance of plasma prolactin levels and of characters reflecting LH synthesis and release

\begin{tabular}{|c|c|c|c|c|c|c|}
\hline \multirow[b]{2}{*}{ Character } & \multicolumn{2}{|c|}{ Oestrogen } & \multicolumn{2}{|c|}{ Bromocriptine } & \multicolumn{2}{|c|}{ Interaction } \\
\hline & $F$ & $P$ & $F$ & $P$ & $F$ & $P$ \\
\hline \multicolumn{7}{|l|}{ Before ovariectomy } \\
\hline Plasma LH & 0.14 & NS & 0.47 & NS & 0.31 & NS \\
\hline Pulse frequency & 0.52 & NS & 0.08 & NS & 0.26 & NS \\
\hline Pulse amplitude & $2 \cdot 7$ & NS & $1 \cdot 2$ & NS & 0.07 & NS \\
\hline \multicolumn{7}{|l|}{ After ovariectomy } \\
\hline Plasma LH & 247 & $<0.001$ & 2.9 & NS & 0.3 & NS \\
\hline LH pulse frequency & 363 & $<0.001$ & $2 \cdot 1$ & NS & 1.9 & NS \\
\hline LH pulse amplitude & $24 \cdot 1$ & $<0.001$ & 0.9 & NS & 0.6 & NS \\
\hline LH-RH priming effect ratio & 4.8 & $<0.05$ & $1 \cdot 1$ & NS & 0.5 & NS \\
\hline LH-RH responsiveness & 116 & $<0.001$ & $7 \cdot 1$ & $<0.05$ & 1.0 & NS \\
\hline Pituitary LH concentration & 171 & $<0.001$ & $4 \cdot 0$ & NS & $1 \cdot 3$ & NS \\
\hline Plasma prolactin & 1.5 & NS & 1030 & $<0.001$ & $1 \cdot 5$ & NS \\
\hline
\end{tabular}

NS, not significant, $P>0.05$.

al. (1977). This study extends their findings by demonstrating associated marked falls in pituitary LH content and in LH-RH responsiveness. Studies of sheep (Coppings \& Malven, 1976), rats (Cooper, Fawcett \& McCann, 1974) and pigs (Pomerantz, Foxcroft \& Nalbandov, 1975) suggest that the inhibitory effect of oestradiol on plasma LH involves a decreased release of LH-RH and decreased pituitary responsiveness to LH-RH. The decreased responsiveness to LH-RH in oestrogen-treated ewes probably reflected a direct effect of oestradiol on pituitary responsiveness to $\mathrm{LH}-\mathrm{RH}$ and also the reduced pituitary $\mathrm{LH}$ content. The small increase in priming effect ratio reflected an action of oestrogen described previously for rats (Aiyer, Sood \& Brown-Grant, 1976), women (Lasley, Wang \& Yen, 1975) and ewes (Wright, Stelmasiak \& Chamley, 1980).

The increased LH-RH responsiveness associated with bromocriptine treatment may have reflected the increased $(P<0.1)$ pituitary LH content. Bromocriptine treatment resulting in increased pituitary $\mathrm{LH}$ in rats was considered to be due to a failure of $\mathrm{LH}$ release associated with reduced synthesis and release of LH-RH (Sheth \& Shah, 1978). However, in this study there was indirect evidence that bromocriptine treatment did not alter LH-RH release since there were 
no alterations in plasma LH levels, pulse frequencies or amplitudes. The administration of prolactin to lactating monkeys (Maneckjee, Srinath \& Moudgal, 1976) and rats (Muralidhar, Maneckjee \& Moudgal, 1977) decreased pituitary LH-RH responsiveness. However, it is unlikely that the increased pituitary LH-RH responsiveness in bromocriptine-treated ewes was due to a removal of an inhibitory effect of prolactin since alterations in prolactin levels in lactating ewes by treatment with bromocriptine (Kann et al., 1978) or ergocornine (Louw et al., 1976) and in ovariectomized ewes by prolactin infusions (Chamley, 1978) did not affect LH-RH responsiveness. Short-term treatment of ovariectomized cows with prolactin failed to influence the pattern of release of LH (Forrest, Fleeger, Long, Sorenson \& Harins, 1980), suggesting that in this species also alterations in plasma prolactin levels were not associated with alterations in LH-RH release or in pituitary LH-RH responsiveness. An understanding of the basis of any changes occurring in studies of bromocriptine-treated ewes is complicated by the confounding of the effects of bromocriptine and of lowered prolactin levels. Interpretation is further complicated because bromocriptine is a dopamine agonist (Fuxe et al., 1978); prolactin, in rats at least, increases dopamine turnover (Hökfelt \& Fuxe, 1972) and the effect of dopamine on LH release is unclear (Jackson, 1977). Bromocriptine did not, however, alter plasma LH levels in this study or in one with cyclic ewes (Niswender, 1974).

This study produced no evidence that the inhibitory effects of oestradiol on plasma LH levels, pituitary LH content and LH-RH responsiveness were enhanced by the high plasma prolactin levels associated with the anoestrous season in sheep. This suggests that there is no causal relationship between elevated plasma prolactin levels and the increased inhibitory effect of oestradiol on plasma LH levels described for ewes in both seasonal (Legan et al., 1977) and post-partum (Wright et al., 1981) anoestrus.

We thank Anne Bartlett and Bev Lando for skilled technical assistance; Dr H. Papkoff and NIH for hormone standards; Dr I. A. Cumming and the Victorian Department of Agriculture for generous co-operation; and Lynn Magill and Jill Volfsbergs for typing. These studies were supported by grants from the Australian Meat Research Committee, the Australian Wool Research Trust Funds and the National Health and Medical Research Council of Australia.

\section{References}

Aiyer, M.S., Sood, M.C. \& Brown-Grant, K. (1976) The pituitary response to exogenous luteinizing hormone releasing factor in steroid-treated gonadectomized rats. J. Endocr. 69, 255-262.

Baird, D.T. (1978) Pulsatile secretion of LH and ovarian estradiol during the follicular phase of the sheep estrous cycle. Biol. Reprod. 18, 359-364.

Burger, H.G., Lee, V.W.K. \& Rennie, G.C. (1972) A generalised computer program for the treatment of data from competitive protein binding assays including radioimmunoassays. J. Lab. clin. Med. 80, 302-312.

Chamley, W.A. (1978) Effect of prolactin on the LH response to synthetic LH-RH in ovariectomized ewes. J. Reprod. Fert. 52, 301-304.

Cooper, W.A., Fawcett, C.A. \& McCann, S.M. (1974) Inhibitory and facilitatory effect of estradiol-17 $\beta$ on pituitary responsiveness to a luteinising hormonefollicle stimulating hormone releasing factor (LHRF/FSH-RF) preparation in the ovariectomized rat. Proc. Soc. exp. Biol. Med. 145, 1422-1426.

Coppings, R.J. \& Malven, P.V. (1976) Biphasic effect of estradiol on mechanisms regulating $\mathbf{L H}$ release in ovariectomized sheep. Neuroendocrinology 21, 146156.

Forrest, D.W., Fleeger, J.L., Long, G.R., Sorenson, A.M. \& Harins, P.G. (1980) Effect of exogenous prolactin on peripheral luteinizing hormone levels in ovariectomized cows. Biol. Reprod. 22, 197-201.

Foster, D.L., Roche, J.F., Karsch, F.J., Norton, H.W., Cook, B. \& Nalbandov, A.V. (1972) Regulation of luteinizing hormone in the fetal and neonatal lamb. 1. LH concentrations in blood and pituitary. Endocrinology 90, 102-111.

Fuxe, K., Fredholm, B.B., Ŏgren, S.O., Agnati, L.F., Hökfelt, T. \& Gustafsson, J.A. (1978) Pharmacological and biochemical evidence for the dopamine agonistic effect of bromocriptine. Acta endocr. Copenh. Suppl. 216, 27-56.

Geschwind, I.I. \& Dewey, R. (1968) Dynamics of luteinizing hormone (LH) secretion in the cycling ewe: a radioimmunoassay study. Proc. Soc. exp. Biol. Med. 129, 451-455. 
Greenwood, F.C., Hunter, W.M. \& Glover, J.S. (1963) The preparation of ${ }^{131}$ I-labelled human growth hormone of high specific radioactivity. Biochem. J. 89, 114-123.

Hökfelt, T. \& Fuxe, K. (1972) Effects of prolactin and ergot alkaloids on the tubero-infundibular dopamine (DA) neurons. Neuroendocrinology 9, 100-122.

Jackson, G.L. (1977) Effect of adrenergic blocking drugs on secretion of luteinizing hormone in the ovariectomized ewe. Biol. Reprod. 16, 543-548.

Kaltenbach, C.C., Schroff, C.L., Klindt, J.M. \& Dunn, T.G. (1972) Disappearance rates of $\mathbf{L H}$ in hypophysectomized ewes. Biol. Reprod. 7, 135, Abstr.

Kann, G. \& Martinet, J. (1975) Prolactin levels and duration of post-partum anoestrus in lactating ewes. Nature, Lond. 257, 63-64.

Kann, G., Habert, R., Meusnier, C. \& Ryniewicz, H.S. (1977) Prolactin release in response to nursing or milking stimulus in the ewe. Is it mediated by thyrotrophin releasing hormone? Annls Biol. anim. Biochim. Biophys. 17, 441-452.

Kann, G., Martinet, J. \& Schirar, A. (1978) Hypothalamic-pituitary-control during lactation in sheep. In Control of Ovulation, pp. 319-333. Eds D. B. Crighton, N. B. Haynes, G. R. Foxcroft \& G. E. Lamming. Butterworths, London.

Karsch, F.J., Dierschke, D.J., Weick, R.F., Yamaji, T., Hotchkiss, J. \& Knobil, E. (1973) Positive and negative feedback control by estrogen of luteinising hormone secretion in the Rhesus monkey. Endocrinology 92, 799-804.

Lasley, B.L., Wang, C.F. \& Yen, S.S.C. (1975) The effects of estrogen and progesterone on the functional capacity of the gonadotrophs. J. clin. Endocr. Metab. $41,820-826$.

Legan, S.L., Karsch, F.J. \& Foster, D.L. (1977) The endocrine control of seasonal reproductive function in the ewe: a marked change in response to the negative feedback action of estradiol on luteinizing hormone secretion. Endocrinology 101, 818-824.

Lincoln, G.A. (1978) Hypothalamic control of the testis in the ram. Int. J. Androl. 1, 331-341.

Louw, B.P., Lishman, A.W., Botha, W.A., Arangie, P.A.R., Poultney, B.G. \& Gunter, M.J. (1976) The release of luteinizing hormone in ewes deprived of prolactin during lactation. S. Afr. J. Anim. Sci. 6, 87-91.

Maneckjee, R., Srinath, B.K. \& Moudgal, N.R. (1976) Prolactin suppresses release of luteinising hormone during lactation in the monkey. Nature, Lond. 262, 507.
Mauleon, P. \& Dauzier, L. (1965) Variations de durée de l'anoestrus de lactation chez le brebis de race Ile-de-France. Annls Biol. anim. Biochim. Biophys. 5, 131-143.

Muralidhar, K., Maneckjee, R. \& Moudgal, N.R. (1977) Inhibition of the in vivo pituitary release of luteinising hormone in lactating rats by exogenous prolactin. Endocrinology 100, 1137-1142.

Niswender, G.D. (1974) Influence of 2-Br- $\alpha$-ergocryptine on serum levels of prolactin and the estrous cycle in sheep. Endocrinology 94, 612-615.

Pomerantz, D.K., Foxcroft, G.R. \& Nalbandov, A.V. (1975) Acute and chronic estradiol-17 $\beta$ inhibition of LH release in prepubertal female pigs: time course and site of action. Endocrinology 96, 558-663.

Rogol, A.D. \& Rosen, S.W. (1974) Alteration of human and bovine prolactins by a chloramine $\mathrm{T}$ radioiodination: Comparison with lactoperoxidase-iodinated prolactins. J. clin. Endocr. Metab. 39, 379-382.

Sheth, A.R. \& Shah, P.G. (1978) Effect of bromocryptine on the hypothalmic-pituitary function in adult male rats. Life Sci. 22, 2137-2140.

Shevah, Y., Black, W.J.M., Carr, W.R. \& Land, R.B. (1974) The effect of lactation on the resumption of reproductive activity and the pre-ovulatory release of LH in Finn $\times$ Dorset ewes. J. Reprod. Fert. 38, 369-378.

Snook, R.B. (1968) Immunological and biological properties of antiserum to bovine LH. Excerpta Med. Int. Cong. Ser. 161, 398-400.

Stelmasiak, T. \& Galloway, D.B. (1977) A priming effect of LH-RH on the pituitary in rams. J. Reprod. Fert. 51, 491-493.

Thimonier, J., Ravault, J.P. \& Ortavant, R. (1978) Plasma prolactin variations and cyclic ovarian activity in ewes submitted to different light regimes. Annls Biol. anim. Biochim. Biophys. 18, 1229-1235.

Walton, J.S., MeNeilly, J.R., MeNeilly, A.S. \& Cunningham, F.J. (1977) Changes in concentrations of follicle-stimulating hormone, luteinising hormone, prolactin and progesterone in the plasma of ewes during the transition from anoestrus to breeding activity. J. Endocr. 75, 127-136.

Wright, P.J., Stelmasiak, T. \& Chamley, W.A. (1980) Pituitary responsiveness to LH-RH in post-partum ewes treated with oestradiol-17 $\beta$ and failing to show a plasma LH surge. Aust. J. biol. Sci. 33, 465-469.

Wright, P.J., Geytenbeek, P.E., Clarke, I.J. \& Findlay, J.K. (1981) Evidence for a change in oestradiol negative feedback and LH pulse frequency in post-partum ewes. J. Reprod. Fert. 61, 97-102.

Received 17 November 1980 